\title{
Pre- and postsynaptic effect of galanin on excitatory synaptic transmission in rat spinal dorsal horn neurons
}

\author{
Hai-Yuan Yue, Tsugumi Fujita, Tao Liu, Lian-Hua Piao, Chang-Yu Jiang \\ Kotaro Mizuta, Terumasa Nakatsuka, and Eiichi Kumamoto
}

Department of Physiology, Faculty of Medicine, Saga University

[Received 29 January 2009, Accepted 19 March 2009]

\begin{abstract}
Galanin, a 29/30 amino acid neuropeptide, and three types (GalR1-3) of receptors for this neuropeptide, which are expressed in rat dorsal root ganglion neurons and spinal dorsal horn neurons, play a pivotal role in regulating nociceptive transmission to the spinal dorsal horn from the periphery. Intrathecal administration of galanin in rats modulates nociceptive behavior in a biphasic manner such that galanin at low and high doses produces nociception and antinociception, respectively. In order to know cellular mechanisms for this effect, we investigated the effect of galanin on glutamatergic spontaneous excitatory synaptic transmission in substantia gelatinosa (SG) neurons of adult rat spinal cord slices by use of the wholecell patch-clamp technique. In $83 \%$ of the neurons examined $(n=29)$, galanin $(0.03 \mu \mathrm{M})$ superfused for 2 min increased the frequency of spontaneous excitatory postsynaptic current (sEPSC) recorded at $-70 \mathrm{mV}$ without a change in its amplitude and also in holding currents. The remaining neurons produced a small outward $(n=4)$ or inward current $(n=1)$. This presynaptic effect was dose-dependent with an EC50 value of $0.0029 \mu \mathrm{M}$, and was mimicked by a selective GalR2/R3 agonist galanin (2-11) but not a selective GalR1 agonist M617. Superfusing galanin at a higher dose such as $0.1 \mu \mathrm{M}$ for 2 min produced an outward current in $39 \%$ of SG neurons tested $(\mathrm{n}=33)$. Twelve $\%$ of the $\mathrm{SG}$ neurons had an inward current and the remaining neurons did not change holding currents. The outward current produced by galanin had an EC50 value of $0.042 \mu \mathrm{M}$, and was mimicked by M617 but not galanin (2-11). The sEPSC frequency increase and outward current persisted in the presence of a $\mathrm{Na}^{+}$-channel blocker tetrodotoxin. It is concluded that galanin at lower doses enhances the spontaneous release of $\mathrm{L}-$ glutamate from nerve terminals by activating GalR2/R3 while galanin at higher doses produces a membrane hyperpolarization by activating GalR1 in the SG. This pre- and postsynaptic effects could contribute to at least a part of the behavioral effect of galanin.
\end{abstract}

Key words: Galanin; Excitatory transmission; Spinal dorsal horn; Rat; Patch-clamp technique 


\section{ラット脊䯣後角ニューロンの興奮性シナプス伝達に対する \\ ガラニンのシナプス前性および後性作用}

岳 海源 /藤田 亜美 / 柳 涛 / 朴 蓮花 /蒋 昌宇

水田 恒太郎/中塚 映政/熊本 栄一

佐賀大学医学部 生体構造機能学講座 (神経生理学分野)

\section{はじめに}

ガラニンは $29 / 30$ 個のアミノ酸残基からなる 神経ペプチドの 1 つで，摂食や痛みなどの様々 な生理作用に重要な役割を果たしている 15,19)。 ガラニン受容体は, 現在, 3 種類 (GalR1-3) が クローニングされており，いずれも $\mathrm{G}$ タンパク 質共役型である 15)。ガラニンが皮膚末梢から 脊䯣後角に至る痛み伝達の制御に関与すること を示す多くの証拠がある。例えば，（1）後根神 経節や脊髄後角におけるガラニン様免疫活性と ガラニン受容体 mRNA の存在 ${ }^{2,20)}, \quad(2)$ ガラニ ンの脊䯣腔内投与により皮膚末梢に与えられた 痛み刺激に対する応答が修飾されること $3,13,16)$, （3）足底へのカラゲニン投与による炎症で誘起 される後根神経節や春䯣後角におけるガラニン mRNA 量の変化 ${ }^{9)}$, (4) 後根神経節においてガ ラニンを過剩発現させたトランスジェニックマ ウスにおける痛み行動の変化 7) である。

脊髄後角の膠様質 (Rexed の第 II 層) は, 皮膚 末梢からの痛み情報がグルタミン酸作動性の 1 次求心性線維により後根を通って単シナプス 性，あるいは興奮性や抑制性の介在ニューロン を介して多シナプス性に入力する部位である。 この膠様質がオピオイドやアデノシンをはじめ 多くの内因性鎮痛物質による痛み情報伝達の制 御に重要な役割を果たすことは数多くの研究に より明らかにされている5,6,12,22)。若齢ラット
(3〜6 週齢) の膠様質ニューロンの興奮性シナプ ス伝達に及ぼすガラニン受容体の作動薬や阻害 薬の作用はごく最近報告されているが 1), ガラ ニン自身の作用はまだ調べられていない。我々 は, 春髄の痛み伝達制御におけるガラニンの役 割の詳細を知る目的で, 成熟ラット脊髄横断ス ライスの膠様質ニューロンヘブラインド・ホー ルセル・パッチクランプ法を適用し, 自発性興 奮性シナプス伝達に及ぼすガラニンの効果を調 ベた。

\section{方法}

本実験の計画は佐賀大学動物実験委員会の審 査を受けて承認された。

\section{1. 脊髄スライス標本の作製}

尙髄横断スライスは, 以前の報告と同様に 23 , 24), Sprague-Dawley 系の成熟雄性ラット（6〜 7 週齢) から作製した。まず，ウレタン $(1.2 \sim 1.5$ $\mathrm{g} / \mathrm{kg}$ を腹腔内投与）で深麻酔したラットを加温 パッドの上で腹臥位とした。そして, 腰仙部の 椎弓切除を行い, $1.5 \sim 2.0 \mathrm{~cm}$ の長さで切り出し た L1〜S3 レベルの春䯣を酸素飽和した人工脳 脊髄液 $\left(2 \sim 4{ }^{\circ} \mathrm{C}\right)$ に浸した。実体顕微鏡下で硬膜 を除去した後，後根および前根をすべて切除 し, その後, クモ膜や軟膜を除去した。このよ うな脊髄断片を寒天ブロックに設けた浅い溝の 
上に置き，マイクロスライサー（堂阪イーエム の DTK-1000）を用い約 $650 \mu \mathrm{m}$ の厚さの脊髄横 断スライスを作製した。切り出したスライスを 直ちに記録用チェンバー内のナイロンメッシュ の上に置き，上から銀線に装置した EM グリッ ドで軽く固定した。そのスライスの両面を酸素 負荷すると共に加温 $\left(36 \pm 1{ }^{\circ} \mathrm{C}\right)$ した人工脳脊䯣 液により 15〜20 ml/分の速度で灌流した。人工 脳脊髄液 (クレブス液) の組成 $(\mathrm{mM})$ は, $\mathrm{NaCl}$, 117; $\mathrm{KCl}, 3.6 ; \mathrm{CaCl}_{2}, 2.5 ; \mathrm{MgCl}_{2}, 1.2 ; \mathrm{NaH}_{2} \mathrm{PO} 4$, 1.2; glucose, 11; $\mathrm{NaHCO} 3,25 （ \mathrm{pH}=7.4 ）$ であっ た。

\section{2. 脊髄膠様質ニューロンからの パッチクランプ記録}

実体顕微鏡下 $(20 \sim 40$ 倍) に打いて, 脊䯣スラ イスヘ下方から透過光を当てると, 膠様質は後 角の灰白質部表層に位置する半透明なバンド状 として視認可能である。以前の報告と同様に 23 , 24)，パッチ電極を膠様質に刺入し，ギガオー ム・シールを形成した後, 膠様質ニューロンか らホールセル記録を行った。パッチ電極は入力 抵抗が 10 15 M $\Omega$ のもを用い, その内液組 成 (mM) は, K-gluconate, $135 ; \mathrm{KCl}, 5 ; \mathrm{CaCl} 2,0.5$; $\mathrm{MgCl}$, 2; EGTA, 5; HEPES, 5; Mg-ATP, 5 (pH = 7.2 )であった。膜電位固定下の自発性興奮性 ナプス後電流 (spontaneous excitatory postsynaptic current: sEPSC) は, $-70 \mathrm{mV}\left(\mathrm{Cl}^{-}\right.$チャネル電流 の逆転電位）の保持膜電位で記録した。この膜 電流をパッチクランプ用増幅器（HEKA 社製の EPC-7）により増幅し， A/D 変換（Molecular Devices 製の Digidata 1200）後，デー夕記録お よび解析用のソフトゥェア (Molecular Devices 製の pCLAMP 9）を用いてコンピューターによ り記録・解析した。sEPSC は non-NMDA 受容 体阻害剂である CNQX $(10 \mu \mathrm{M})$ 存在下で消失す
るので神経終末から放出されたグルタミン酸に よるシナプス後細胞の non-NMDA 受容体活性 化によることがわかる23,24)。また， SEPSC は $\mathrm{Na}^{+}$チャネル阻害剤であるテトロドトキシン （TTX; $0.5 \mu \mathrm{M} ）$ により影響を受けないので，そ の発生は膠様質ニューロンヘシナプス入力する 興奮性ニューロンの興奮によるものではない23, 24)。実験結果は平均 \pm 標準誤差 (S.E.M.) で表 し, 検定は Student の t-test で行い, 危険率 5\% 未満 $(\mathrm{p}<0.05)$ をもて有意と判定した。括弧内 の $\mathrm{n}$ の值は記録したニューロンの数である。

使用した薬物について，ガラニンはペプチド 研究所 (大阪) から, galanin (2-11) は SigmaAldrich から, TTX は和光純薬から購入し, M617 はU. Sollenberg 氏（スウェーデンのス トックホルム大学）から供与された。無 $\mathrm{Ca}^{2+}$ 液 は $\mathrm{Mg}^{2+を ~} 5 \mathrm{mM}$ 含んで扮り, 浸透圧は $\mathrm{Na}^{+}$濃度 を下げることにより調整した。

\section{結果}

ガラニンの作用は, $-55 \mathrm{mV}$ より深い静止膜 電位を持つ 180 個の膠様質ニューロンから -70 $\mathrm{mV}$ の保持膜電位で調べられた。すべての ニューロンは下向きに記録される時間経過の速 い膜電流である sEPSC を示した。

\section{1. ガラニンのシナプス前性作用}

ガラニン $(0.03 \mu \mathrm{M})$ を 2 分間灌流投与すると, Fig.1-A で示すように，調べたニューロン $(\mathrm{n}=$ 29)の $83 \%$ で保持膜電流の変化なしに sEPSC の 発生頻度が増加した。Fig.1-B は, sEPSC の発 生頻度と振幅に及ぼすガラニン $(0.03 \mu \mathrm{M})$ の作 用の経時変化を示している。ガラニン投与開始 後 2 分位から発生頻度が増加し始め, ガラニン 


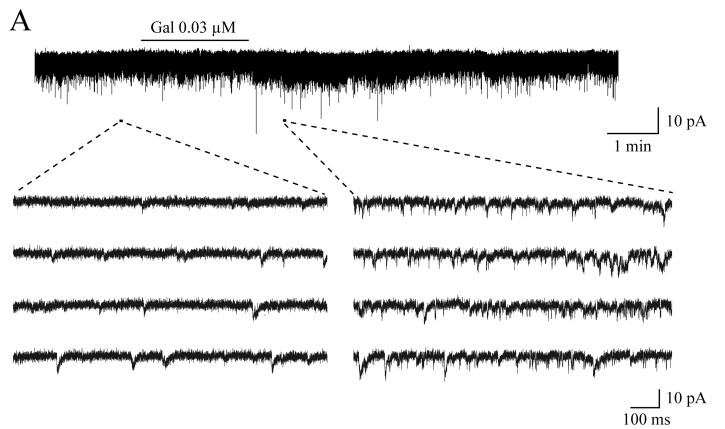

B

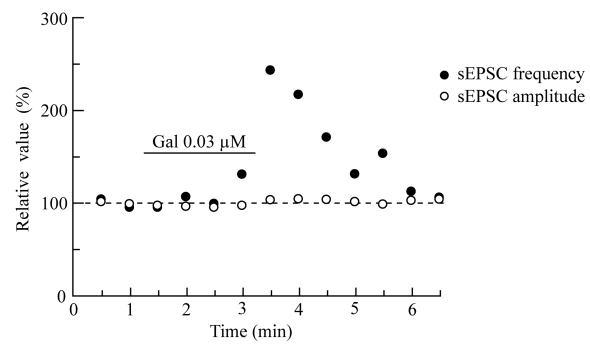

Fig.1 Galanin (Gal; $0.03 \mu \mathrm{M})$ presynaptically enhances glutamatergic spontaneous excitatory synaptic transmission in substantia gelatinosa (SG) neurons.

(A) Recordings of sEPSCs in the absence and presence of Gal. In this and subsequent figures, duration of drug superfusion is shown by a horizontal bar above chart recording and consecutive traces of sEPSCs for a period indicated by a short bar below the chart recording are shown in an expanded time scale. (B) Time courses of changes in the frequency $(\bullet)$ and amplitude $(\bigcirc)$ of sEPSC under the action of Gal, relative to control; they were measured every 0.5 min. Holding potential $(\mathrm{VH})=-70 \mathrm{mV}$.

除去後，4 分位でコントロールレベルに戻った。 この増加は振幅の変化を伴っていなかった。ガ ラニン投与開始後 2.5 分に打ける sEPSC の発生 頻度と振幅は, それぞれコントロールの $166 \pm$ $13 \%(\mathrm{n}=24 ; \mathrm{p}<0.05)$ と $101 \pm 1 \%(\mathrm{n}=24 ; \mathrm{p}>0.05)$ であった。残りの 5 個のニューロンのうち 4 個 のニューロンは $4.2 \pm 0.3 \mathrm{pA}(\mathrm{n}=4)$ の振幅を持つ 外向き膜電流を, 1 個のニューロンは $2.4 \mathrm{pA} の$ 内向き膜電流を生じた。このように保持膜電流 が変化したニューロンでは SEPSC の分析を行 わなかった (後述)。

ガラニン $(0.03 \mu \mathrm{M})$ による sEPSC の発生頻度
A
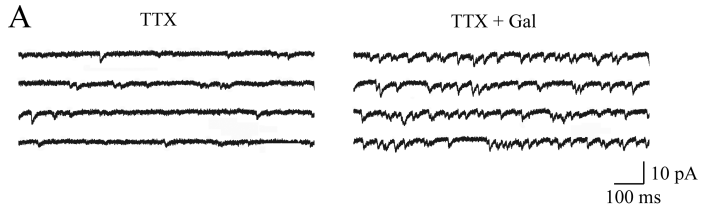

B
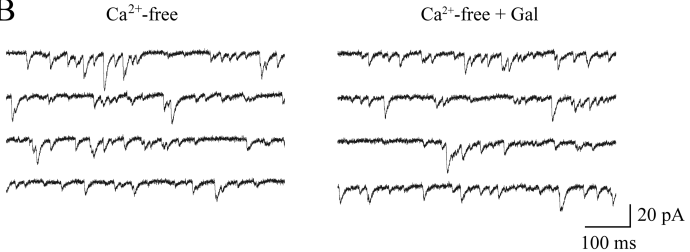

Fig.2 The presynaptic effect of galanin is resistant to a voltage-gated $\mathrm{Na}^{+}$-channel blocker tetrodotoxin (TTX; $0.5 \mu \mathrm{M}$ ) and sensitive to extracellular $\mathrm{Ca}^{2+}$ concentration.

Recordings of sEPSCs in the absence and presence of Gal in TTX-containing (A) or nominally- $\mathrm{Ca}^{2+}$ free Krebs solution (B). $\mathrm{VH}=-70 \mathrm{mV}$.

増加は TTX $(0.5 \mu \mathrm{M})$ 存在下で影響を受けなかっ た $($ Fig.2-A)。ガラニン投与開始後 2.5 分におい て, 調べたニューロン（n=16）の $75 \%$ で保持膜 電流の変化なしに sEPSC の発生頻度が $61 \pm$ 29\%（n=12; $<<0.05 ）$ だけ増加し，この值は TTX なしの場合の值 $(66 \pm 13 \% ; n=24)$ と比べて異 なっていなかった（ $\mathrm{p}>0.05)$ 。残りのニューロン は sEPSC の発生頻度の増加を示さなかった。無 $\mathrm{Ca}^{2+}$ 液中でガラニン $(0.03 \mu \mathrm{M})$ の作用を調べた ところ, Fig.2-Bで示すように, 調べたニュー ロン $(\mathrm{n}=10)$ のすべてにおいて, 保持膜電流や自 発性興奮性シナプス伝達の変化はみられず，ガ ラニン投与開始後 2.5 分に扔ける sEPSC の発生 頻度と振幅は，それぞれコントロールの $103 \pm$ $3 \%(n=10 ; p>0.05)$ と $100 \pm 1 \%(n=10 ; p>0.05)$ で あった。

ガラニンによる sEPSC の発生頻度増加は濃 度依存性であり，0.001 $\mu \mathrm{M}$ のような低濃度では 作用はみられず， $0.01 \mu \mathrm{M} ， 0.03 \mu \mathrm{M}$ と濃度の増 加と共に作用は大きくなったが, $0.3 \mu \mathrm{M}$ まで増 

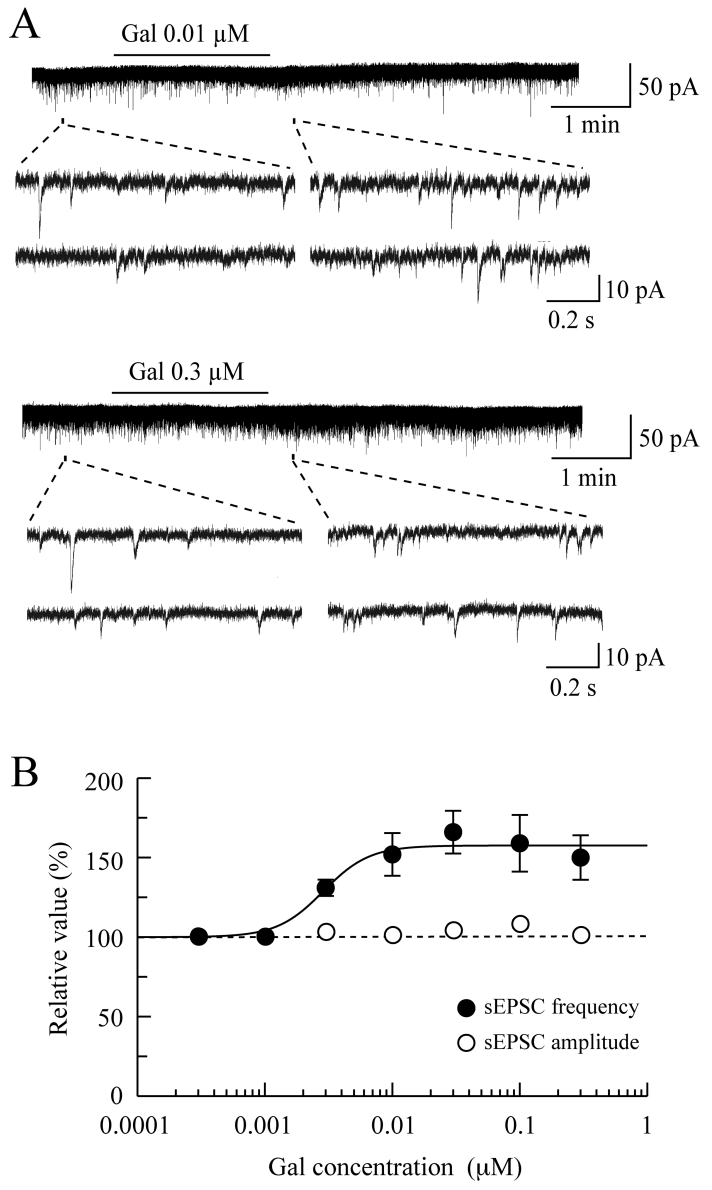

Fig.3 The presynaptic effect of galanin is dose-dependent.

(A) Recordings of sEPSCs in the absence and presence of Gal at $0.01 \mu \mathrm{M}$ (upper) or $0.3 \mu \mathrm{M}$ (lower). (B) Dose-response curves for the frequency $(\bullet)$ and amplitude $(\bigcirc)$ of sEPSC under the action of Gal, relative to control, in neurons which did not change holding currents. Here, were plotted data obtained from neurons which increased sEPSC frequency by $>5 \%$ in response to Gal. The proportions of neurons sensitive to Gal at $0.0003,0.001,0.003,0.01,0.03,0.1$ and $0.3 \mu \mathrm{M}$ were $0 / 8(0 \%), 0 / 4(0 \%), 5 / 11$ (45\%), $5 / 7$ (71\%), 20/24 (83\%), 11/15 (73\%) and 8/11 (73\%), respectively. Remaining neurons did not change sEPSC frequency over $5 \%$. In this and subsequent figures, each point with vertical bars represents the mean and S.E.M.; the S.E.M. of the values without a vertical bar was within the size of symbol. The solid line was drawn according to the Hill equation; the EC50 value was $0.0029 \mu \mathrm{M}$ (Hill coefficient: 2.4 ). $\mathrm{VH}=-70 \mathrm{mV}$.

加すると逆に小さくなる傾向がみられた (Fig.3-

A)。ガラニンの濃度が高くなると, 外向き膜電 流を誘起するニューロンの割合が増えたが（後

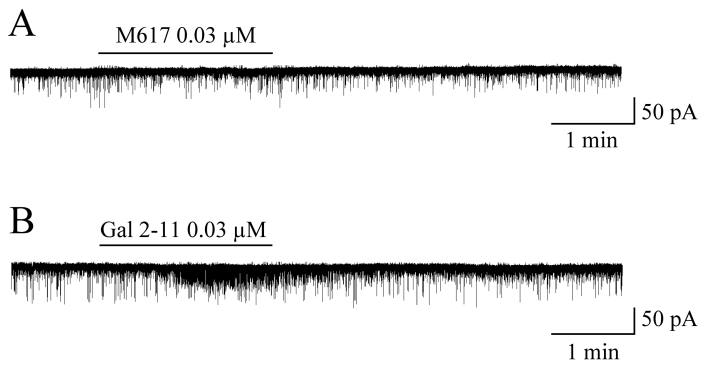

Fig.4 The presynaptic effect of galanin is mediated by GalR2/R3 but not GalR1.

Recordings of sEPSCs in the absence and presence of a GalR1 agonist M617 $(0.03 \mu \mathrm{M}$; A) or a GalR2/R3 agonist galanin (2-11) (Gal 2-11; $0.03 \mu \mathrm{M} ; \mathbf{B}) . \mathrm{VH}=-70 \mathrm{mV}$.

述), この電流存在下では短絡効果により sEPSC の振幅を正確に見積もることができない ので保持膜電流の変化がないニューロンにおい てのみ SESPCの定量的な解析を行った。Fig.3B は，保持膜電流の変化のないニューロンにお ける $\mathrm{sEPSC}$ の振幅と発生頻度に対するガラニ ンの作用の濃度依存性を示している。0.003 $\mu \mathrm{M}$ から $0.3 \mu \mathrm{M}$ の範囲で振幅は変化せずに発生頻 度のみが濃度の増加と共に増加した。Hill プ ロットに従って解析すると, 最大効果の半分を 示す濃度である EC50は $0.0029 \mu \mathrm{M}$ （Hill 係数 = 2.4)であった。

Fig.4 はガラニン受容体作動薬が自発性興奮 性シナプス伝達に及ぼす作用を示している。 GalR1 の作動薬である M617 (0.03 $\mu \mathrm{M})$ は, Fig.4A で示すように，その発生頻度に影響を及ぼさ ず，投与開始後 2.5 分でコントロールの $101 \pm$ $2 \%(\mathrm{n}=4 ; \mathrm{p}>0.05)$ であった。一方, GalR2/R3 の作動薬である galanin（2-11）（0.03 $\mu \mathrm{M} ）$ は発 生頻度を増加させ (Fig.4-B), 投与開始後 2.5 分 でコントロールの $180 \pm 18 \% （ \mathrm{n}=4 ; \mathrm{p}<0.05 ）$ で あった。これらのいずれの作動薬も SEPSCの 振幅には影響しなかった。 
A

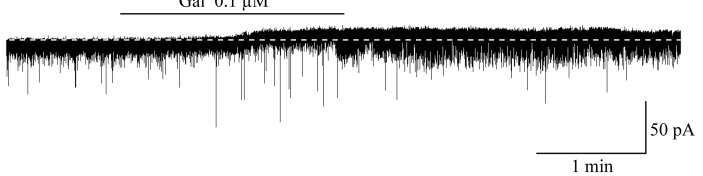

B

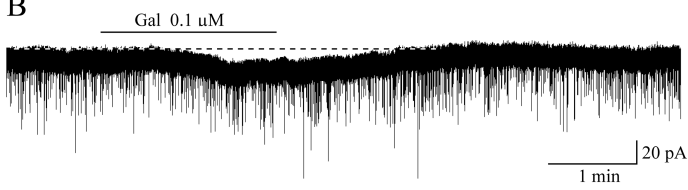

Fig.5 Two types of changes in holding currents following galanin $(0.1 \mu \mathrm{M})$ superfusion in SG neurons.

Thirty-nine \% of the neurons examined $(n=33)$ showed an outward current, as seen in (A), while $12 \%$ of them had an inward current (B). Remaining neurons (49\%) did not postsynaptically respond to Gal. $\mathrm{VH}=-70 \mathrm{mV}$.

A Gal $0.03 \mu \mathrm{M}$

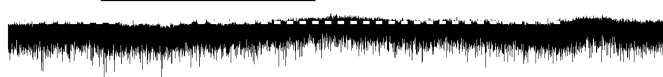

Gal $1 \mu \mathrm{M}$

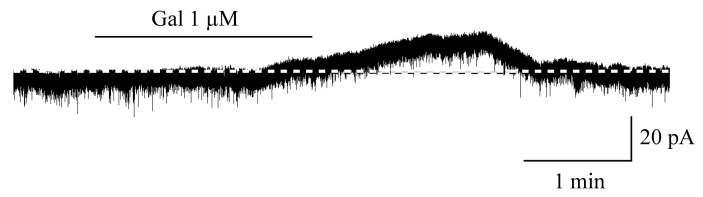

B

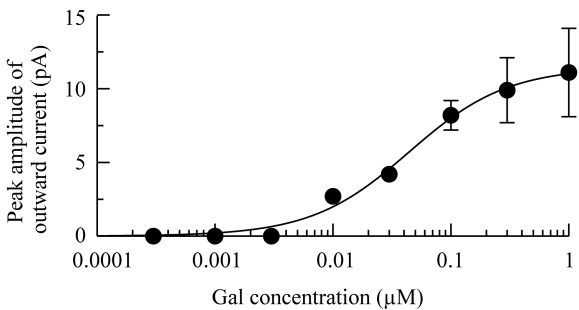

Fig.6 Galanin produces an outward current in a dosedependent manner.

(A) Chart recording showing an outward current produced by Gal at 0.03 or $1 \mu \mathrm{M}$. (B) Peak amplitudes of outward currents elicited by Gal at various concentrations, which were plotted against the logarithm of Gal concentration. The proportions of neurons which produced outward currents in response to $\mathrm{Gal}$ at $0.0003,0.001,0.003,0.01$, $0.03,0.1,0.3$ and $1 \mathrm{\mu M}$ were $0 / 8(0 \%), 0 / 4(0 \%), 0 / 11(0 \%)$, $1 / 9(11 \%), 4 / 29(14 \%), 13 / 33(39 \%), 11 / 24(46 \%)$ and $4 / 6$ (67\%), respectively. Gal at $0.01,0.03,0.1,0.3$ and $1 \mu \mathrm{M}$ produced inward currents in $11 \%, 3 \%, 12 \%, 4 \%$ and $13 \%$ of the neurons tested, respectively, while the remaining neurons did not respond to Gal. The solid line was drawn according to the Hill equation; the EC50 value was 0.044 $\mu \mathrm{M}$ (Hill coefficient: 1.0). $\mathrm{VH}=-70 \mathrm{mV}$.
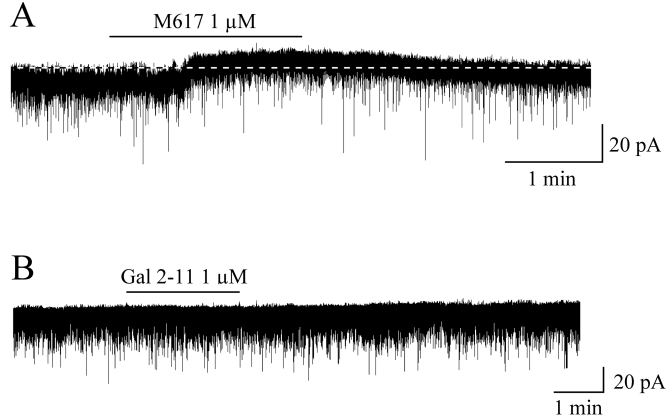

Fig.7 Galanin-induced outward current is mediated by GalR1 but not GalR2/R3 in SG neurons.

Chart recording in the absence and presence of M617 (1 $\mu \mathrm{M}$; A) or Gal 2-11 (1 $\mu \mathrm{M} ; \mathrm{B}) . \mathrm{VH}=-70 \mathrm{mV}$.

\section{2. ガラニンのシナプス後性作用}

$0.1 \mu \mathrm{M}$ のような高い濃度のガラニンを 2 分間 灌流投与すると, Fig.5-A で示すように，調べ たニューロン（n=33）の $39 \%$ で外向き膜電流が 誘起された。その振幅の大きさは $8.0 \pm 0.9 \mathrm{pA}$ $(\mathrm{n}=13)$ であった。残りのニューロンのうち $12 \%$ は $5.3 \pm 1.8 \mathrm{pA}(\mathrm{n}=4)$ の振幅を持つ内向き膜電流 を（Fig.5-B)， $49 \%(n=16)$ は保持膜電流の変化 を示さなかった。

Fig.6-A はガラニンの外向き膜電流誘起作用 の濃度依存性を示している。 $0.03 \mu \mathrm{M}, 0.1 \mu \mathrm{M}$ ， $1 \mu \mathrm{M}$ と, その濃度の増加と共に外向き膜電流 の振幅の大きさ，また，外向き膜電流を誘起す るニューロンの割合が増加した。Fig.6-B は多 くのニューロンから得られた結果をまとめたも ので，外向き膜電流の振幅をガラニン濃度に対 してプロットした濃度ー応答曲線を示してい る。Hill プロットに従って解析したところ， EC50 值は $0.044 \mu \mathrm{M}$ （Hill 係数は 1.0）であった。 このようなガラニン作用は, sEPSC の発生頻度 の増加と同様, TTX $(0.5 \mu \mathrm{M})$ 存在下でもみられ た $(n=4)$ 。 
ガラニン受容体の作動薬が保持膜電流に及ぼ す作用を調べたところ，M617（1 $\mu \mathrm{M})$ は調べた ニューロン $(\mathrm{n}=10)$ の $70 \% て ゙ ~ 9.1 \pm 2.2 \mathrm{pA}(\mathrm{n}=7)$ の振幅を持つ外向き膜電流を誘起し（Fig.7-A）， 残りのニューロンでは保持膜電流を変化させな かった。一方, galanin $(2-11) （ 1 \mu \mathrm{M})$ は調べた すべてのニューロン $(\mathrm{n}=10)$ で保持膜電流を変化 させなかった (Fig.7-B)。

\section{考 察}

本研究は, 脊髄膠様質ニューロンにおいて, ガラニンが SEPSC の振幅を変えずにその発生 頻度を増加させること, つまり, シナプス後細 胞の non-NMDA 受容体のグルタミン酸感受性 を変えずに神経終末からのグルタミン酸放出を 促進することを明らかにした。また，ガラニン は-70 mVにおいて, 多くのニューロンで外向 き膜電流，いくつかのニューロンで内向き膜電 流を誘起することを明らかにしたが，この保持 電位は静止膜電位付近であるので，それぞれ， 膜の過分極と脱分極に対応している。グルタミ ン酸放出促進と膜過分極のいずれも TTXによ り影響を受けなかったのでガラニンの直接作用 であることがわかる。グルタミン酸放出促進作 用は膜過分極作用よりも低い濃度でみられ, 前 者の作用の $\mathrm{EC} 50$ 值は後者の作用のものよりも 約 15 倍だけ小さかった。

グルタミン酸放出促進は GalR2/R3 の作動薬 である galanin (2-11) でみられることょり GalR2/R3 の活性化を介することが示唆され る。この結果と一致して, 春髄や後根神経節で GalR2 と GalR3 の mRNA の存在が示されてい る20)。また, 膜過分極は GalR1 の作動薬であ る M617 でみられることより GalR1 の活性化を
介することが示唆される。この考えを支持する ことには, 脊髄後角のニューロンに GalR1 蛋白 が発現していることが報告されている14)。以 上の結果は, 低濃度のガラニンは GalR2/R3 を 活性化する一方, 高濃度のガラニンは GalR1 を 活性化することを示しているが，これは結合実 験による GalR1，GalR2，GalR3 に対するガラ ニンの親和性とは逆の結果であった。すなわ ち, ガラニンの結合親和性は GalR1, GalR2, GalR3 の順に小さくなった ${ }^{4)}$ 。これはガラニン がその受容体に結合した後に起こるグルタミン 酸放出促進と膜過分極のそれぞれに至る細胞内 機序の違いに起因する可能性があるが, 今後, この点を検討する必要がある。ガラニンそれ自 身は用いられなかったが, 若齢ラットの膠様質 ニューロンの興奮性シナプス伝達において我々 のものと似たような結果が薬理学的手法により 得られている1)。すなわち, 神経終末では GalR2 の活性化がグルタミン酸放出を促進する 一方，シナプス後細胞では GalR1 活性化による 内向き整流性の伝導度の増加や GalR2 活性化に よる外向き整流性の伝導度の増加および減少が 起こることが明らかにされている。小腸の筋層 間ニューロンや脳弓下器官ニューロンではガラ ニンにより膜過分極が誘起されること ${ }^{10,18)}$ ，ま た，前脳基底部のコリン作動性ニューロンでは ガラニンにより様々な種類の $\mathrm{K}^{+}$チャネルが抑 制されることが報告されている ${ }^{8)}$ 。ガラニンに よる脊咀膠様質ニューロンの膜電位の変化にど んな種類のイオンチャネルの開閉が関与してい るかは今後調べる必要がある。

脊䯣膠様質ニューロンは痛み伝達の制御に重 要な役割を果たす部位であり,オピオイドやア デノシンのような内因性鎮痛物質により膜過分 極やグルタミン酸放出抑制が誘起される 5,12$) 。$ 


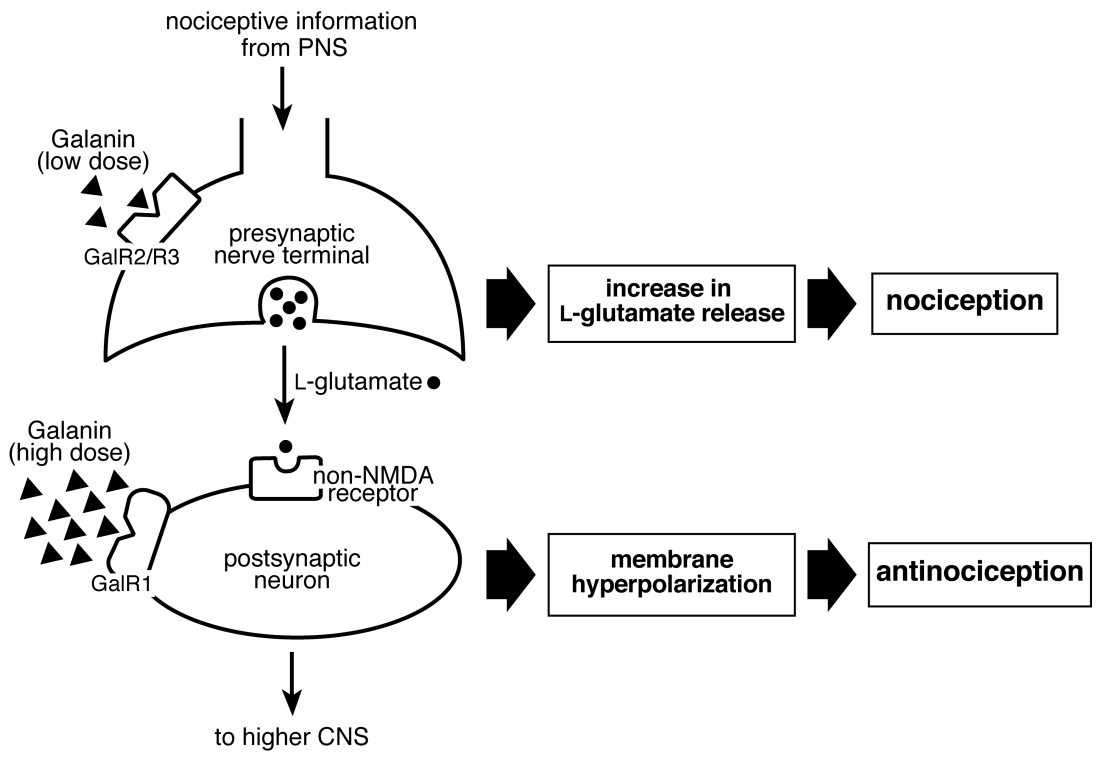

Fig.8 Schematic diagram showing the effect of galanin on glutamatergic excitatory synaptic transmission in SG neurons.

Gal at low doses activates GalR2/R3 in nerve terminals to increase the release of $\mathrm{L}$-glutamate to $\mathrm{SG}$ neurons while Gal at high doses acts on GalR1 in postsynaptic neurons to produce a membrane hyperpolarization. The former action increases the excitability of SG neurons and the latter one decreases its excitability; they could contribute to nociception and antinociception, respectively.

本研究により明らかにされた低濃度のガラニン による GalR2/R3 活性化を介したグルタミン酸 放出促進と高濃度のガラニンによる GalR1 活性 化を介した膜過分極は，それぞれ痛み伝達の促 進と抑制に関与することが示唆される (Fig.8)。 この結果と一致して, 行動生理学の実験によ り, 脊䯣腔内に投与されたガラニンは, 低濃度 では疼痛, 高濃度では鎮痛を起こすことが明ら かにされているし21)，前者の作用には GalR2， 後者の作用には GalR1 が関与していることが示 されている16)。

\section{結 語}

ガラニンは低濃度で GalR2/R3 を活性化して 膠様質ニューロンへのグルタミン酸放出を促進
し, 高濃度で GalR1 を活性化して膠様質ニュー ロンの膜を過分極することが明らかとなった。 グルタミン酸放出の促進は疼痛を発生させ, 膜 の過分極は鎮痛を引き起こすと考えられる。こ れらの結果からガラニンは脊髄後角における痛 み伝達制御に細胞レベルの機序で寄与すると推 察される。いくつかの膠様質ニューロンでガラ ニンにより膜の脱分極が起こるが，この薬理学 的性質や発生機序を今後調べる必要がある。最 近，ラット背側縫線核ニューロンでガラニンが 神経末端からの GABA 放出を抑制すると報告 されている17)。痛み伝達の制御には抑制性シ ナプス伝達の修飾も関与しているので ${ }^{11)}$, ガ ラニンがこの伝達にどんな影響を及ぼすかも今 後の検討課題である。 


\section{文 献}

1) Alier, K.A., Chen, Y., Sollenberg, U.E., Langel, Ü., Smith, P.A., Selective stimulation of GalR1 and GalR2 in rat substantia gelatinosa reveals a cellular basis for the anti- and pro-nociceptive actions of galanin, Pain, 137 (2008) 138-146.

2) Ch'ng, J.L.C., Christofides, N.D., Anand, P., Gibson, S.J., Allen, Y.S., Su, H.C., Tatemoto, K., Morrison, J.F.B., Polak, J.M., Bloom, S.R., Distribution of galanin immunoreactivity in the central nervous system and the responses of galanin-containing neuronal pathways to injury, Neuroscience, 16 (1985) 343-354.

3) Cridland, R.A., Henry, J.L., Effects of intrathecal administration of neuropeptides on a spinal nociceptive reflex in the rat: VIP, galanin, CGRP, TRH, somatostatin and angiotensin II, Neuropeptides, 11 (1988) 23-32.

4) Florén, A., Land, T., Langel, Ü., Galanin receptor subtypes and ligand binding, Neuropeptides, 34 (2000) 331-337.

5) Fujita, T., Nakatsuka, T., Kumamoto, E., Opioid receptor activation in spinal dorsal horn. In: E Kumamoto (Ed), Cellular and Molecular Mechanisms for the Modulation of Nociceptive Transmission in the Peripheral and Central Nervous Systems, Research Signpost, India, 2007, pp87-111.

6) Fürst, S., Transmitters involved in antinociception in the spinal cord, Brain Res. Bull., 48 (1999) 129141.

7) Holmes, F.E., Bacon, A., Pope, R.J.P., Vanderplank, P.A., Kerr, N.C.H., Sukumaran, M., Pachnis, V., Wynick, D., Transgenic overexpression of galanin in the dorsal root ganglia modulates pain-related behavior, Proc. Natl. Acad. Sci. USA, 100 (2003) 6180-6185.

8) Jhamandas, J.H., Harris, K.H., MacTavish, D., Jassar, B.S., Novel excitatory actions of galanin on rat cholinergic basal forebrain neurons: implications for its role in Alzheimer's disease, J. Neurophysiol., 87 (2002) 696-704.

9) Ji, R.-R., Zhang, X., Zhang, Q., Dagerlind, Å., Nilsson, S., Wiesenfeld-Hallin, Z., Hökfelt, T., Central and peripheral expression of galanin in response to inflammation, Neuroscience, 68 (1995) 563-576.

10) Kai, A., Ono, K., Kawano, H., Honda, E., Nakanishi, O., Inenaga, K., Galanin inhibits neural activity in the subfornical organ in rat slice preparation, Neuroscience, 143 (2006) 769-777.

11) Kohno, T., A role of spinal inhibition in neuropathic pain. In: E Kumamoto (Ed), Cellular and Molecular Mechanisms for the Modulation of
Nociceptive Transmission in the Peripheral and Central Nervous Systems, Research Signpost, India, 2007, pp131-145.

12) Kumamoto, E., Fujita, T., Role of adenosine in regulating nociceptive transmission in the spinal dorsal horn. In: SG Pandalai (Ed), Recent Res Devel Physiol, Vol. 3, Research Signpost, India, 2005, pp39-57.

13) Kuraishi, Y., Kawamura, M., Yamaguchi, T., Houtani, T., Kawabata, S., Futaki, S., Fujii, N., Satoh, M., Intrathecal injections of galanin and its antiserum affect nociceptive response of rat to mechanical, but not thermal, stimuli, Pain, 44 (1991) 321-324.

14) Landry, M., Bouali-Benazzouz, R., André, C., Shi, T.J.S., Léger, C., Nagy, F., Hökfelt, T., Galanin receptor 1 is expressed in a subpopulation of glutamatergic interneurons in the dorsal horn of the rat spinal cord, J. Comp. Neurol., 499 (2006) 391-403.

15) Lang, R., Gundlach, A.L., Kofler, B., The galanin peptide family: receptor pharmacology, pleiotropic biological actions, and implications in health and disease, Pharmacol. Ther., 115 (2007) 177-207.

16) Liu, H.-X., Brumovsky, P., Schmidt, R., Brown, W., Payza, K., Hodzic, L., Pou, C., Godbout, C., Hökfelt, T., Receptor subtype-specific pronociceptive and analgesic actions of galanin in the spinal cord: selective actions via GalR1 and GalR2 receptors, Proc. Natl. Acad. Sci. USA, 98 (2001) 99609964.

17) Sharkey, L.M., Madamba, S.G., Siggins, G.R., Bartfai, T., Galanin alters GABAergic neurotransmission in the dorsal raphe nucleus, Neurochem. Res., 33 (2008) 285-291.

18) Tamura, K., Palmer, J.M., Winkelmann, C.K., Wood, J.D., Mechanism of action of galanin on myenteric neurons, J. Neurophysiol., 60 (1988) 966-979.

19) Tatemoto, K., Rökaeus, Å., Jörnvall, H., McDonald, T.J., Mutt, V., Galanin - a novel biologically active peptide from porcine intestine, FEBS Lett., 164 (1983) 124-128.

20) Waters, S.M., Krause, J.E., Distribution of galanin$1,-2$ and -3 receptor messenger RNAs in central and peripheral rat tissues, Neuroscience, 95 (2000) 265-271.

21) Wiesenfeld-Hallin, Z., Villar, M.J., Hökfelt, T., The effects of intrathecal galanin and C-fiber stimulation on the flexor reflex in the rat, Brain Res., 486 (1989) 205-213.

22) Willis, Jr. W.D., Coggeshall, R.E., Sensory Mechanisms of the Spinal Cord. 2nd edition, Plenum Press, New York, 1991, pp94-115. 
23) Yue, H.-Y., Fujita, T., Kawasaki, Y., Kumamoto, E., AM404 enhances the spontaneous release of Lglutamate in a manner sensitive to capsazepine in adult rat substantia gelatinosa neurones, Brain Res., 1018 (2004) 283-287.
24) Yue, H.-Y., Fujita, T., Kumamoto, E., Phospholipase A2 activation by melittin enhances spontaneous glutamatergic excitatory transmission in rat substantia gelatinosa neurons, Neuroscience, 135 (2005) 485-495.

Address for correspondence: Eiichi Kumamoto

Department of Physiology, Faculty of Medicine, Saga University

5-1-1 Nabeshima, Saga 849-8501, Japan

TEL: 0952-34-2273 / FAX: 0952-34-2013

E-mail: kumamote@cc.saga-u.ac.jp 